\title{
Collective Wisdom and Practical Knowledge: the New Christian Journal for Global Health
}

\section{The Editors}

The Christian Journal for Global Health is an initiative of the Center for Health in Mission. It reflects a broad and expanding collaborative movement involving a large number of individuals and organizations globally. There is a rich history of efforts in health care by people of faith with courage to change with the times. This has inspired the concept of a Christian journal to explore global health issues in a manner that reflects scholarly excellence and scientific credibility.

We seek to capture, catalogue and distribute Christian thinking and practice that has been forged in real-time service among those in need. These experiences, and the motivations underlying them, warrant expression in an open access format, available world-wide and without cost. We hope to bring a scholarly approach to global health problems, marked by critical analysis and practical application to the world our readers inhabit. This journal will give voice to Christian workers, in every area of the world seeking best practices combined with common values. Few journals have as integrative an approach to health and mission, science and faith, policy and practice as we hope for this multidisciplinary resource. Our aim is to maintain a missional call to bless the nations and promote the power of the gospel to heal the whole person, community and society. With interdenominational global contribution and distribution, we hope to create new conversations using the comments feature and social media platforms.

To make this project sustainable and effective, we are calling for papers from around the world: editorials, review articles, original articles, case studies, short communications, field reports, current debates, commentaries, study design articles, capac- ity building articles, conference reports, and book reviews. These contributions will cover one or more of the following areas:

- Public Health (Health Promotion/Prevention, Nutrition and Food Security, Maternal and Child Health, Community Development)

- Health Care Services (Primary Health Care, Surgical Service, Disaster and Emergency, Rehabilitative services, Mental Health, Palliative Care)

- Organization (Administration and Finance, Policy and Advocacy, Workforce)

- Mission and Health (Theology, Evangelism, Community Transformation)

- Conditions of Special Interest (HIV/AIDS, Non-Communicable Disease, Neglected Tropical Diseases, Ethics)

Following the Scriptures which guide our work, we value strength in weakness, humility over bravado, evidence over superstition, honest appraisals over self-serving anecdotes, values over expediency. Recognizing the value of the perspectives of our colleagues of various world views, we hope true wisdom can be applied to express in writing cohesive knowledge for the good of others. As the source of all good gifts, and the reconciler of relationships, God will be glorified, and the Church's role in healing the whole person and all nations will be enhanced.

The tides of change in global health must include people of faith who retain and express the wisdom of God with a relevant Grand Narrative. By letting this light shine, as Jesus taught, it becomes a 
testimony to the presence and glory of God among the peoples of the world.

The current issue embodies the original call for papers that speak to the past, present and future of global health work that is inspired and informed by a Christian world view. Ted Lankester's guest editorial is a call to commitment to broader Christian engagement in global health movements with an affirmation of the role the Christian Journal for Global Health might play in those efforts.

This is followed by three historical reviews. Professor Grundmann summarizes the history of medical missions with a focus on the tension that has always existed between evangelism and service. His denouement of this tension is thoughtful, encouraging and relevant for today. The Rev. Canon Ted Karpf reviews the relationship between faithbased organizations and official government organizations with all their ups and downs and offers an honest appraisal of the opportunities and difficulties. Dr. Reena George tells the moving story of the call of Ida Scudder to missionary service and the subsequent evolution of that call into the institution known throughout the world as Christian Medical College, Vellore, India. This article particularly highlights the opportunity offered by the new journal to describe events best described as Christian formation - personal and historical, but informed by spiritual understanding and illumination.

The present is illustrated by two original articles, one describing a successful contextualized intervention for HIV prevention among the Massai in Tanzania, and the other reports on the challenges facing the Catholic Church in India in the provision of healthcare for their elderly, especially those with neurodegenerative illness. An important aim of the journal is to show the integration of faith and health and this is well illustrated by a short communication on HIV home care in Zambia. For the present and heading to the future, we require a robust theological understanding of our mission. Apollos Landa offers a thoughtful commentary on what ought to be the full framework for healthcare. Ken Foster offers a proposal on what might be done for greater integrity in improving and maintaining professional training standards in countries where these lag behind.

We also feature two book reviews. Matthew Santosh Thomas' review of a book by Peter and Jean Rookes takes us from the past through the present into the future with a look at the organization and financing of medical missionary work in two specific contexts. Meredith Long's balanced and fair review of a book describing the faith-inspired motivations and activism of Dr. Paul Farmer in his selfless and insightful efforts to help the medically underserved.

Our prayer is that we can give a leading voice from Christian thinkers, workers and leaders around the world, particularly those from majority world countries, who are ministering to millions of people suffering from illness and deprivation. By promoting intelligent scholarship we aim to see improvements in quality care, and to articulate theological reflections that inspire a new generation of service in a broken world. This project would not have come to fruition without hours of voluntary labor from a team of dedicated editors, reviewers, artists, technicians, donors and writers. They have been aptly supported by an expert team of advisors. We are pleased to be launching this inaugural issue of the Christian Journal for Global Health and are confident it will become everything we hope it will be.

\section{www.cjgh.org}

